\title{
Asymmetric Salary and Uniformity of Academic Positions at Universities in the EU28
}

\author{
Benedetto Torrisi \\ Business and Economics Department, Economic Statistical Area, University of Catania, Catania, Italy \\ Email: btorrisi@unict.it
}

How to cite this paper: Torrisi, B. (2016) Asymmetric Salary and Uniformity of Academic Positions at Universities in the EU28. Open Access Library Journal, 3: e3198. http://dx.doi.org/10.4236/oalib.1103198

Received: November 4, 2016

Accepted: December 11, 2016

Published: December 14, 2016

Copyright $\odot 2016$ by author and Open Access Library Inc.

This work is licensed under the Creative Commons Attribution International License (CC BY 4.0).

http://creativecommons.org/licenses/by/4.0/ (c) (i) Open Access

\begin{abstract}
The asymmetries academic salary theme comparisons fit in the context of topics such as the measurement of productivity, academic labour market, welfare organization and brain drain. From the research of academic positions for each European country, we imagined the standardization of the academic positions into a single European model, according to the bonds of the similarity of roles between the countries that were analysed. The objective of this paper is to demonstrate whether it is possible to design a European model of standard academic positions and salaries and what are the determining factors for differences. This objective was achieved by creating a data set of official data and applied multivariate methodologies: clustering, regression model, ANOVA and inferential statistics. This study proves that in Europe it is not possible to hypothesize a single model of salaries for academics and it demonstrates the reasons.
\end{abstract}

\section{Subject Areas}

Development Economics, Human Resource Management, Labor Economics

\section{Keywords}

Asymmetries Salary, Academic Salary, Standard Academic

\section{Introduction}

There are not complex comparative studies on earnings between academics from different countries because they often lack statistical data on this theme. Another reason lies in the institutional diversity of the individual countries.

It's difficult to generalize wages in 28 different States such as Europeans because bonuses, allowances and supplements cause a change in the wage in relation to the roles, the institution and the countries [1]. 
For example: In Italy, the academic salary has one component, the basic salary. In other European States, the salary includes: the basic component, another components and a merit component. Salary is defined as the most common standard for international comparisons regarding pay. Indeed, salary is the reference variable on which the employer (the university) calculates costs and benefits. The sum of the gross salary places the burden on the employer, the university, and is the total cost of the teaching staff. The gross salary is also the basis on which the national government and the citizens regulate each other's shareholding relationships. Therefore, we will refer to the gross salary in regard to the evaluations.

If you need to evaluate the differences between the wages we can not limit ourselves to conversion of the currency, as we lose that piece of information related to the cost of living. Wages are often analysed using the PPP (Purchasing Power Parity) conversion rate and the Big Mac index. The PPP conversion factor incorporates the cost of living. Therefore, the PPP conversion factor provides a basis for comparing wages in different international contexts. The PPP helps us to overcome the difficulties of comparison generated by the market's exchange rate, which is unable to reflect the real cost of living in different countries.

In Slovenia, the institutions may determine salaries in accordance with the law concerning institutes of the public sector and two types of collective agreements.

In Finland, there are many systems wages based on the legal status of each institution and the contracts that are entered into as a result of collective agreements.

In the Czech Republic, Estonia, Austria and Liechtenstein, the definition of these scales is the sole responsibility of the institutions.

However, in Sweden, the salaries are defined individually for each employee based on performance, not on the basis of a scale.

In Latvia, the salaries are established by institutions, and their rate should not be lower than the rates set by the central government.

In Luxembourg, the university provides a grid of wages that must then be approved by the Ministry of Higher Education.

In Malta, the university council or the governors, inside the Malta College of Arts, Science and Technology (MCAST), defines gross annual salaries through the Understanding with the Ministry of Education.

In Spain, salaries are established jointly between the State and the institutions for non-employees. In Lithuania, this situation applies to fellows.

In Denmark, wages are exclusively the result of a collective agreement between the Danish confederation, professional associations (Akademikernes Centralorganisation) and the Ministry of Finance. The Netherlands, Sweden and the UK are characterized by a strong decision-making autonomy of their institutions regarding the definition of annual salaries. In Sweden, salaries are determined on an individual basis, after negotiations that occur exclusively at the institutional level. Salaries are then based on a collective agreement, the unions and the Swedish Agency for Government Employees, which represents public employers. All of the salaries are set by the institutions, except 
that of the Vice-Chancellors (determined by the government).

In most countries, except the French and German Communities of Belgium, Ireland, Sweden and Norway, wages are expected to be premium wages, often based on the length of service and/or the performance of academic staff.

In most countries, the definition process of salary scales (which allows for, beginning from a basic salary minimum, the progression of the teaching staff during their professional career to the maximum salary) is based on national legislation and other official, central documents.

In certain countries (such as Finland, Ireland, Malta, Portugal and Slovenia), the salary scales result from a negotiation between the State and institutions or unions. In the UK, the negotiation of wages occurs through a specific body called the Joint Negotiating Committee for Higher Education Staff (JNCHES). Institutions will agree on the common scales (except for the type of senior staff, the more qualified) and then determine the salaries. These scales are negotiated nationally through the mechanism of the Joint Negotiating Committee for HE Staff (JNCHES). The negotiation occurs between the associations of university and college employers and the various unions involved that represent the staff.

Comparing the salaries of the countries [2] belonging to the European Union requires certain preliminary observations. Salary levels vary both within countries and between the countries. Depending on the national legislation and the university governance, wage levels can be both rigidly fixed by the State or determined by the university.

The wage conditions (including salary scales, bonuses and gross salary) constitute a basis upon which higher education institutions have the right to intervene, although very often the central level retains important prerogatives on most aspects in many countries.

The objective of this paper is to demonstrate whether it is possible to design a European model of standard academic positions and salaries and what are the determining factors for the differences.

This objective was achieved by studying the bibliography, by creating a data set of official data (see paragraph 3 ) and developing methodologies through multivariate analysis (see paragraph 4$)$.

\section{Theoretical Framework}

Even if convergences are to be observed among the orientations adopted by higher education policies in European countries, they still are characterized by strong national features. One of the most striking national patterns of each system is its academic labor market, salaries, status, recruitment procedures, workloads, career patterns, promotion rules, being very different from one country to another. Nevertheless, specific national academic labor markets are experiencing a common evolution that can be summed up by the emergence of more regulated internal labor markets. At the same time, the qualification of the academic production (knowledge) as a public good is questioned and 
academic activities rely less on individual autonomy than before [3].

There are few empirical contributions on the theme of comparison of academic salaries. Despite what mention should be made some interesting contributions on the topic and some attempts to understand the differences in wages between different countries. An empirical attempt is in Greenbaum [4] that explore the relationship among teacher salaries across Pennsylvania school districts.

The investigation "Paying the professoriate", which was created by Philip Altbach and three colleagues from the Center for International Higher Education (Liz Reisberg and Ivan F. Pacheco) [5], provides a global comparison of fees, contracts and benefits of university professors.

"Paying the professoriate" is the first comprehensive comparative analysis of faculty salaries, teacher salaries and working conditions. This paper [1] provides an in-depth academic international comparison of wages in twenty-eight countries in the public, private and university research sectors.

The authors of this work highlight the conditions and expectations that characterize the modern academic profession.

The work of the European University Institute by the ACE (Academic Careers Observatory) discusses comparative data on salaries for different academic positions. Here, the main comparison criteria relate to the length of service and academic productivity. For each country that is compared, information is provided regarding: higher education, academic positions, existing recruitment conditions, requirements necessary for career advancement, the number of existing positions, contracts and benefits provided, and gender.

Comparisons of "gender" appear to be the most analysed factor in recent years due to the asymmetry of the gender proportions in the international academic world (Academic Careers Observatory, 2009: Gender Comparisons).

In 2007, Bruegel [6] calculated the "settings of autonomy" in relation to salary in ten European countries and assigned values between 0 and 1 (one maximum autonomy, zero no autonomy). Many countries (Belgium, Germany, Ireland, Italy, Spain and Switzerland) had no autonomy (0). Sweden has the highest autonomy (1); the Netherlands (0.2), Denmark (0.5) and the UK (0.8) are in the middle. The average total for the ten European countries is 0.3 [6].

Another aspect that should be mentioned concerns the strong relationship that exists between the level of wages and productivity. One often reads that countries with greater scientific and academic productivity are those that have higher wages. Should be drawn to on this aspect of the study Richard J. Cebula \& Franklin G. Mixon Jr. \& Mark A. Montez (2013) [7] re-examines the relationships between school performance (at the high school level) and both teacher pay/salaries and teacher quality, where the latter is measured by teachers' human capital.

An educated population is a fundamental ingredient for a well functioning democracy and a crucial driver of growth in the modern economy [8]. Implement a European academic education model involves a balance between the States of wage levels and re- 
turns on education.

From the bibliography generalises the difference between the salaries, but you do not study in relation to the multiple dimensions: the academic role, the level of wealth of a country, variables of context, macroeconomic variables and variables related to the labor contract. Our attempt will overcome this information gap and this is the idea of this paper.

\section{The Variables and Data}

The definition of salary is related to academic positions. We first need to analyse the differences in wages to reclassify academic roles in a European vision and to possibly standardize a single classification model (see Table 1).

From the research on academic positions for each European country, we have imagined a standardization of the academic positions in a single European mode, according to the similarity of roles between the countries analysed.

The official ministries of education for the States are: Ministère de l'éducationnationale de l'enseignementsupérieur et de la recherche for France, Ministerio de Educacion Cultura y Deporte for Spain, the Department for Education for the United Kingdom, and Bundesministeriumfür Bildung, Wissenschaft, Forschung und Technologie for Germany. However, for other States, the main contribution was provided by MORE2 of Brussels [9] [10]; this is a series of more than forty country profiles that summarize the data on academic salary and benefits related to work in the academic sector. Data were collected for the European Commission in 2012 [11] [12] [13] by a network of national experts in the MORE2 study [9] [10]. All academic positions were used by the ministries of education of every country.

According to the analysis of the similarity of the roles, we have created a unique model of European roles: PhD; Post Doc; Assistant Professor Part Time; Assistant Professor Part Time; Assistant Professor Full Time; Associate Professor; Full Professor.

Therefore, in relation to the academic role it is possible to imagine a unique model for all EU states. We found many similarities in the roles though with different nomenclatures, but the contract substance similar.

\section{The Methodology Used}

In statistics, two-dimensional analysis of variance (ANOVA two-way) is an extension of one-way ANOVA that examines the influence of different independent variables on a categorical dependent variable. Although one-way ANOVA measures the effect of a significant independent variable, two-way ANOVA is used when there is more than one independent variable and multiple observations for each independent variable. Two-way ANOVA is able to determine not only the main effect of the contributions of each independent variable but also identifies whether there is a significant interaction effect between the independent variables. In our case, the dependent variable is the salary; the independent variables are the 28 States and the four roles of academic PhDs, Researchers, Associate Professors and Full Professors. 
Table 1. Reclassification of academic positions in European countries.

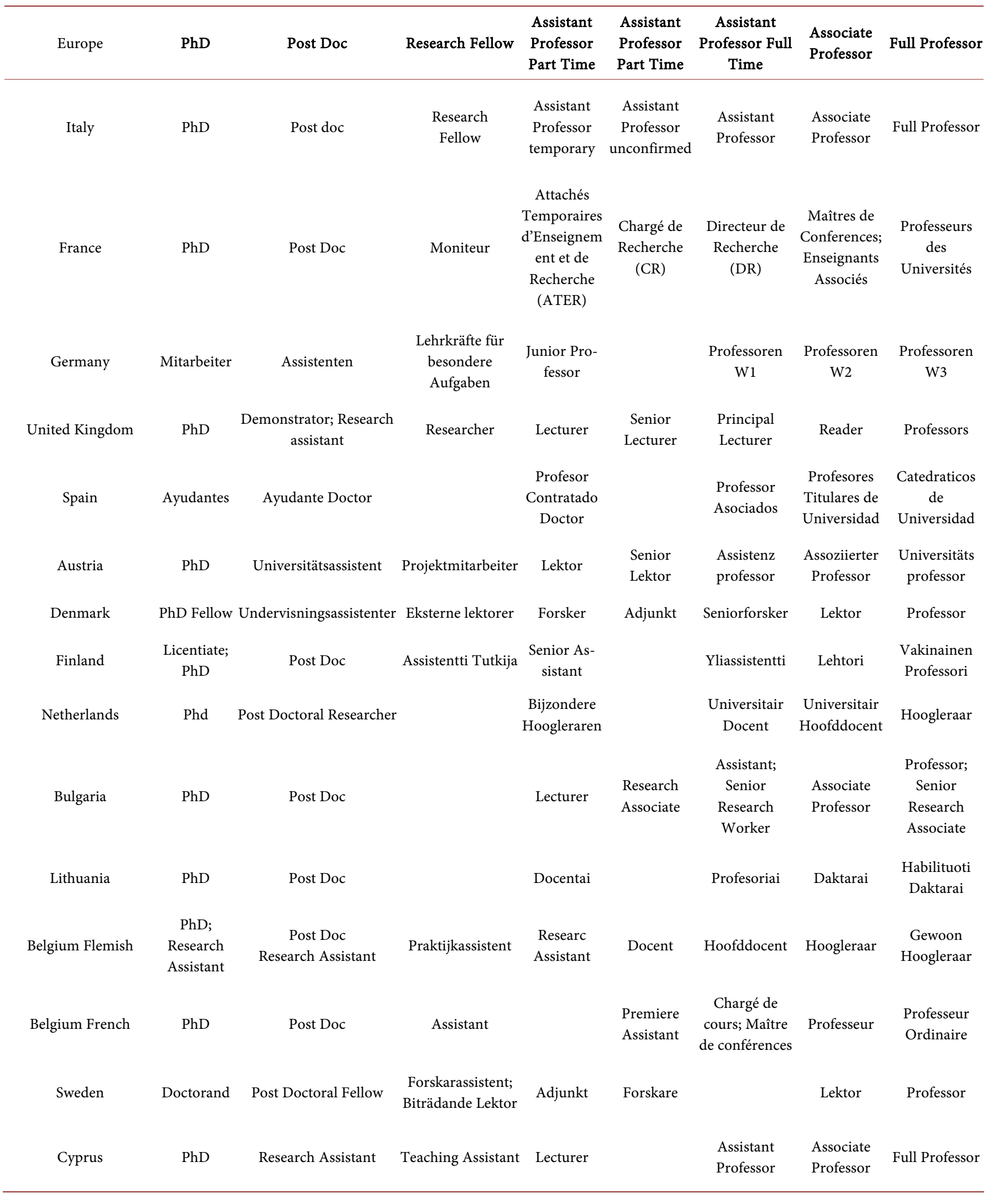




\section{Continued}

\begin{tabular}{|c|c|c|c|c|c|c|c|}
\hline Slovenia & $\begin{array}{l}\text { Doktor } \\
\text { Znanosti }\end{array}$ & Post Doc & $\begin{array}{c}\text { Asistent; } \\
\text { Predavatelji }\end{array}$ & Lektor & $\begin{array}{c}\text { Docent; Višji } \\
\text { Predavatelj }\end{array}$ & $\begin{array}{l}\text { Izredni } \\
\text { Profesor }\end{array}$ & Redni Profesor \\
\hline Ireland & $\begin{array}{c}\text { PhD } \\
\text { Researchers }\end{array}$ & Post Doc & Lecturer & & $\begin{array}{c}\text { Senior } \\
\text { Lecturer }\end{array}$ & $\begin{array}{l}\text { Associate } \\
\text { Professor }\end{array}$ & Professor \\
\hline Greece & $\begin{array}{c}\mathrm{PhD} \\
\text { Candidate }\end{array}$ & Post Doc & Lektoras & & $\begin{array}{l}\text { Epikouros } \\
\text { Kathigitis }\end{array}$ & $\begin{array}{c}\text { Anaplirotis } \\
\text { Kathigitis }\end{array}$ & Kathigitis \\
\hline Hungary & $\begin{array}{c}\mathrm{PhD} \\
\text { Candidate }\end{array}$ & Doctor of the Academy & $\begin{array}{l}\text { Assistant } \\
\text { Lecturer }\end{array}$ & Lecturer & $\begin{array}{c}\text { Kutatò } \\
\text { Professzor }\end{array}$ & Reader & Professor \\
\hline Portugal & $\begin{array}{l}\text { Assistente } \\
\text { Estagiàrio }\end{array}$ & Assistente & & $\begin{array}{c}\text { Professor } \\
\text { Auxiliar }\end{array}$ & & $\begin{array}{l}\text { Professor } \\
\text { Associado }\end{array}$ & $\begin{array}{l}\text { Professor } \\
\text { Catedràtico }\end{array}$ \\
\hline
\end{tabular}

Source: Our elab. About information taken from corporate websites of the Ministries of individual countries-year 2013.

To sample the territorial division of Italy in relation to each aspect, according to the hypotheses made and the different types of behaviour of the phenomenon, groups of variables are used individually according to previous indications. Although the factorial weights are obtained from the 55 variables, 10 macro compound indicators represent the object of the successive elaboration using the Cluvar technique. This technique's objective is the identification of homogeneous groups and the relations between the units (routes) (relations between the individual units and the clusters identified among those variables that have contributed the most to the ties between the units). Particularly, a data table is provided where $\mathrm{x}_{i j}$ represents the determination of $X_{j}$ variable per $j=1, \cdots m$ on the $\mathrm{U}_{i}$ unities per $i=1, \cdots n$. Let $S_{n, m}$ be the correspondent table of the standardized values and $d_{j}$ be the most opportune distance. The matrices $m$ of distance are determined. The technique of grouping "Cluvar" is used for this objective (further details are provided in [14]).

In particular, the Cluvar technique was adopted with the intent of not only extrapolating the homogeneity and non-homogeneity among territorial units but of emphasizing the aspect of variables that interact in the system and all of the relations among unity groups.

In contrast to classical techniques, Cluvar provides the possibility of determining aggregations among statistic techniques emphasizing both the variables that significantly influence cluster determination and the weight that those have on the aggregation definition.

The use of groups of variables has allowed a thematic analysis of the phenomenon and its articulations on the territory; however, the vision of the groups is a consideration of the single aspects and the events caused by their integration. Often, the accu- 
mulation of joint causes generates demonstrations and different behaviours for the usual interpretive models. Regarding this behaviour, further details on the subject can be obtained by applying alternative, but more sophisticated, techniques, for example, the neutral networks (RNA) and the partial last squared (PLS).

\section{Salary Differences Results}

From the results processed on average salaries in different countries and in different academic positions (see Table 2), emerges of strong significant differences. This data can not be read without regard to other macro-economic factors and context. They will be subject to greater respect in the later stages of our paper.

Table 2. Reclassification of the average wages for academic roles in European countries.

\begin{tabular}{|c|c|c|c|c|}
\hline \multirow[t]{2}{*}{ States } & \multicolumn{4}{|c|}{ Salary } \\
\hline & $\mathrm{PhD}$ & Researcher & Associate Professor & Full Professor \\
\hline Austria & $€ 39.24000$ & $€ 45.13200$ & $€ 70.64400$ & $€ 73.26000$ \\
\hline Belgium & $€ 24.30800$ & $€ 30.28800$ & $€ 91.18800$ & $€ 102.22800$ \\
\hline Bulgaria & $€ 6.35700$ & $€ 5.83000$ & $€ 10.59500$ & $€ 12.71500$ \\
\hline Cyprus & $€ 28.78400$ & $€ 38.39900$ & $€ 82.99800$ & $€ 89.72500$ \\
\hline Croazia & $€ 14.42300$ & $€ 15.83600$ & $€ 30.17400$ & $€ 47.57700$ \\
\hline Denmark & $€ 37.82400$ & $€ 36.16800$ & $€ 65.98800$ & $€ 83.68800$ \\
\hline Estonia & $€ 13.63900$ & $€ 16.18800$ & $€ 21.83100$ & $€ 32.70800$ \\
\hline Finland & $€ 13.63900$ & $€ 21.26400$ & $€ 41.04000$ & $€ 62.61600$ \\
\hline France & $€ 23.82000$ & $€ 16.55600$ & $€ 37.75100$ & $€ 40.14000$ \\
\hline Germany & $€ 14.97400$ & $€ 37.79900$ & $€ 43.17900$ & $€ 52.43200$ \\
\hline Greece & $€ 4.84800$ & $€ 12.30000$ & $€ 15.98400$ & $€ 18.44400$ \\
\hline Ireland & $€ 13.57200$ & $€ 30.38600$ & $€ 94.50600$ & $€ 126.99600$ \\
\hline Italy & $€ 13.63800$ & $€ 37.17400$ & $€ 49.78800$ & $€ 65.62200$ \\
\hline Lettonia & & $€ 6.96100$ & $€ 8.71100$ & $€ 10.89400$ \\
\hline Lithuania & $€ 5.81900$ & $€ 9.73100$ & $€ 14.03900$ & $€ 18.04200$ \\
\hline \multicolumn{5}{|l|}{ Lussemburgo } \\
\hline \multicolumn{5}{|l|}{ Malta } \\
\hline Netherlands & $€ 29.68200$ & $€ 56.47600$ & $€ 82.09200$ & $€ 99.10800$ \\
\hline Poland & $€ 4.82600$ & $€ 13.31200$ & $€ 29.86800$ & $€ 42.66800$ \\
\hline Portugal & $€ 20.65000$ & $€ 28.97800$ & $€ 50.94600$ & $€ 61.69600$ \\
\hline Repubblica Ceca & $€ 5.90400$ & $€ 10.94400$ & $€ 15.75600$ & $€ 18.81600$ \\
\hline Romania & $€ 5.09900$ & $€ 6.67600$ & $€ 10.48700$ & $€ 20.67700$ \\
\hline Slovacchia & $€ 5.90400$ & $€ 10.94400$ & $€ 15.75600$ & $€ 18.81600$ \\
\hline Slovenia & $€ 8.40000$ & $€ 36.09600$ & $€ 40.59600$ & $€ 47.49600$ \\
\hline Spain & $€ 17.89600$ & $€ 27.00000$ & $€ 33.00000$ & $€ 43.00800$ \\
\hline Sweden & $€ 32.88000$ & $€ 45.54000$ & $€ 54.96000$ & $€ 77.85600$ \\
\hline United Kingdom & $€ 44.88500$ & $€ 51.15600$ & $€ 72.02400$ & $€ 117.36000$ \\
\hline Hungary & $€ 5.47200$ & $€ 11.57800$ & $€ 14.15100$ & $€ 19.29700$ \\
\hline
\end{tabular}

Lettonia: non è prevista una politica salariale per i candidati PhD. Malta e Lussemburgo: dati mancanti. Source: Our elab. About information taken from corporate websites of the Ministries of individual countries-year 2013. 
The average salary of a $\mathrm{PhD}$ in Europe was $€ 17,459.32$. We find the States with wage levels well above the EU average (see Figure 1) and the percentage differences compared to European average wage, such as the United Kingdom, Austria, Cyprus, Denmark, the Netherlands and Sweden. These results are related, as we shall observe later, to the cost of living and the GDP per capita. Spain and Portugal are at the European average; France and Belgium are slightly above average. Slightly below the European average are Italy $(€ 13,638)$, Ireland, Finland and Germany. However, far below, we find the countries of Eastern Europe and the Balkan Peninsula.

An analysis of the percentage differences compared to European average wage, there are States where the $\mathrm{PhD}$ gains twice the European average wage, by contrast, there are countries with huge negative. For the $\mathrm{PhD}$ in Europe ten twenty-eight countries are above the European average wage.

The average salary for the position of a European Researcher was $€ 25,335.08$ (see Figure 2). Above the European average are the same States that are observed to be above the average for the $\mathrm{PhD}$ role, in addition to Italy (€37,174.00), Germany, Belgium, Portugal and Slovenia. Spain is at the European average. Below the average are the countries of Eastern Europe, the Balkans, the Baltic States, France and Finland. The range of differences is on wages as a percentage than the European average decreases for researchers, compared to $\mathrm{PhD}$. More than $50 \%$ of European countries have levels of salaries for researchers above average with double difference from the European average.

For associate professors, the average wage in Europe is $€ 42,232.77$ (see Figure 3). There are countries, such as Ireland, the Netherlands and Belgium, in which the wages of Associate Professors are twice the European average; Cyprus, Denmark, Italy

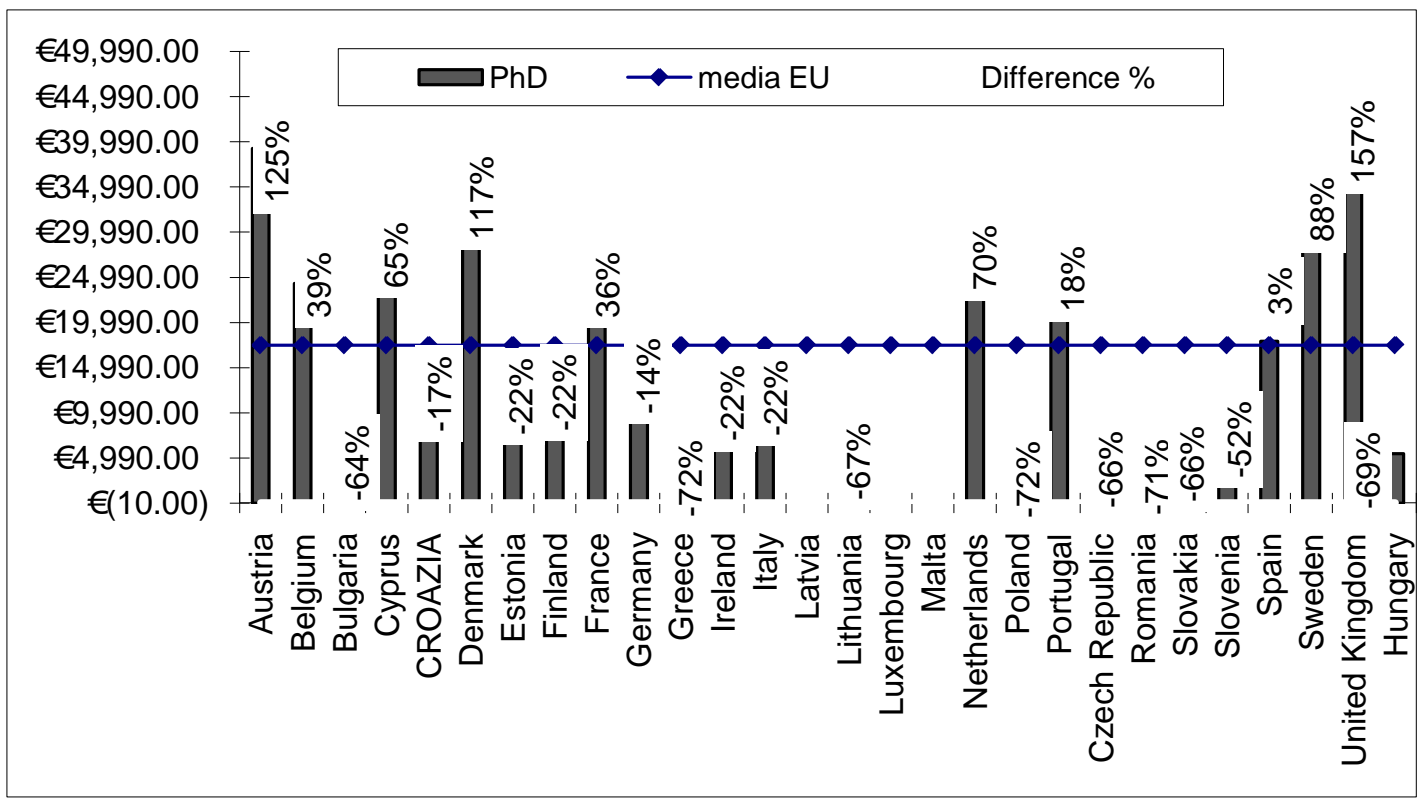

Figure 1. Representation of the average salaries for $\mathrm{PhD}$ role. Source: our elab. About information taken from corporate websites of the Ministries of individual countries-year 2013. 


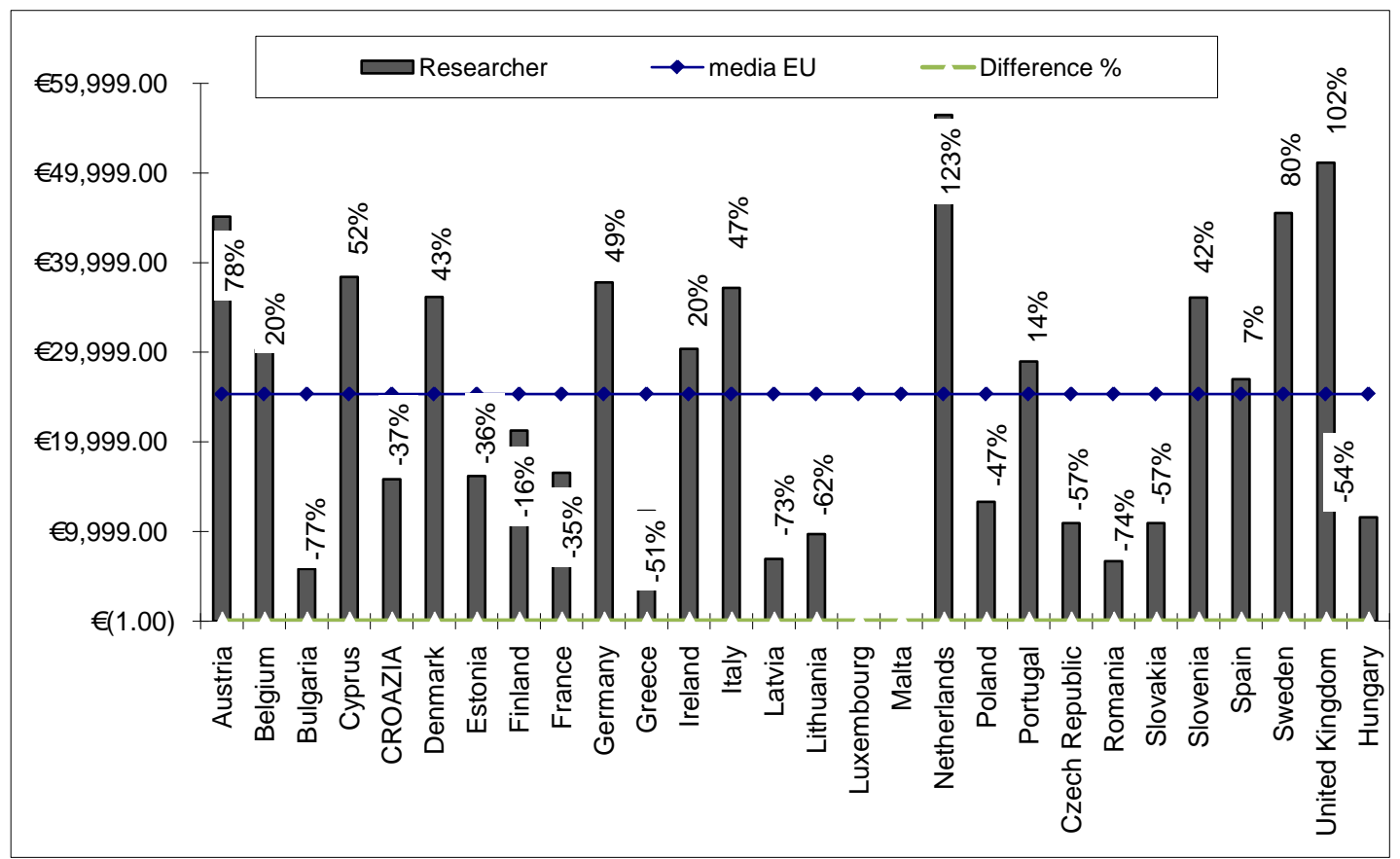

Figure 2. Representation of the average salaries for researchers role. Source: our elab. About information taken from corporate websites of the Ministries of individual countries-year 2013.

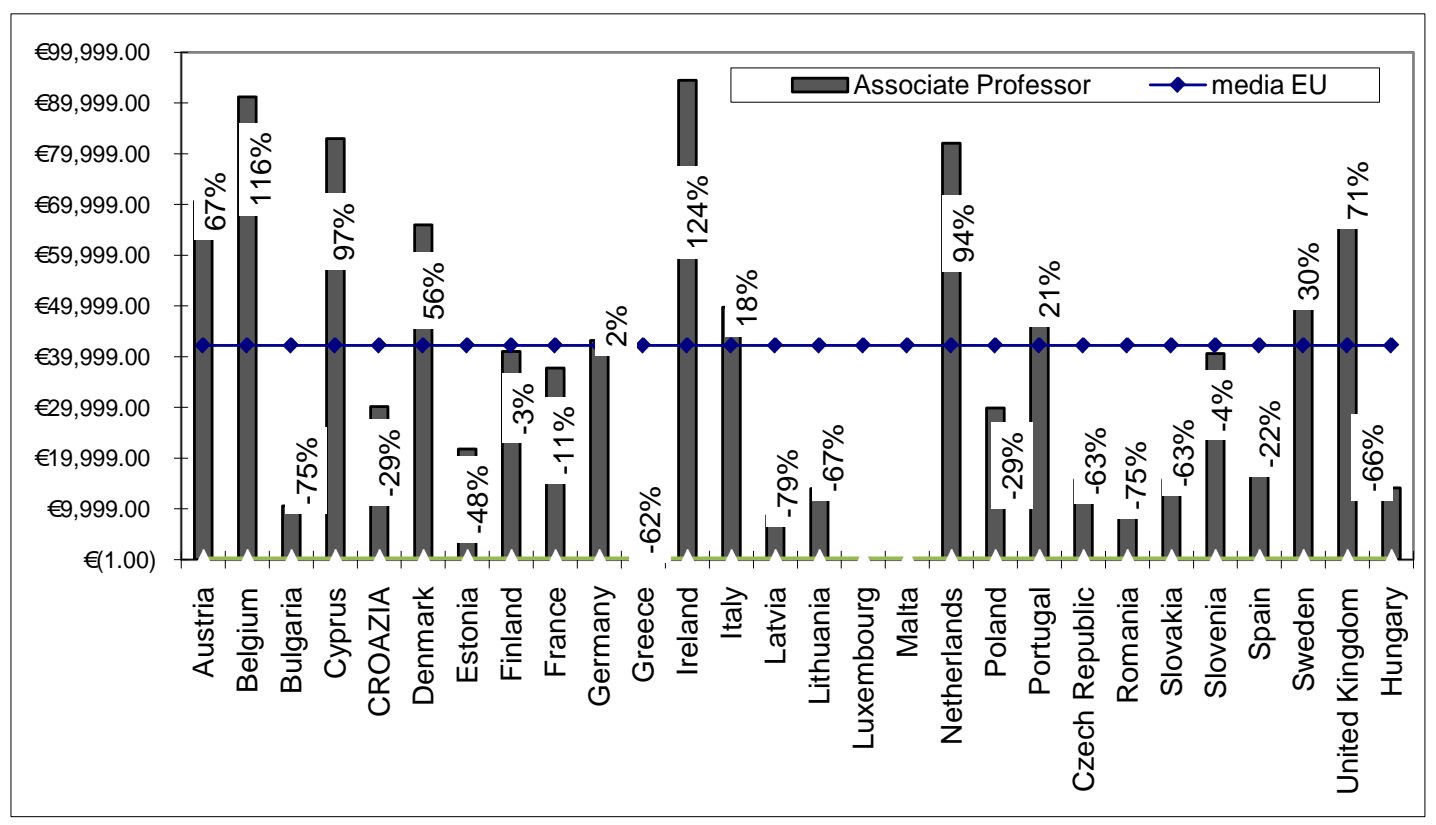

Figure 3. Representation of the average salaries for Associate Professor role. Source: our elab. About information taken from corporate websites of the Ministries of individual countries-year 2013.

$(€ 49,788.00)$, Portugal, Sweden and England are always above the average. At the European average are Finland, Germany and Slovenia. However, far from the European average, are the same countries as for the other two positions.

Ultimately, for the Full Professor position, the average wage in Europe is $€ 53,995.58$ 
(see Figure 4). Ireland and the Netherlands confirm what has been observed for full Professors, and these countries are joined by the United Kingdom. Italy is ranking is above average, whereas Germany is below average.

For associate professors and ordinary (see Figure 3 and Figure 4) are similar trends. In this case only 11 States out of 28 have higher wages than the European average. These results are consistent with the wages and $\mathrm{PhD}$ researchers. That resulting from the first analysis is a mapping of wages in quite differentiated Europe. One wonders then for what reasons and what factors infuenzano these wage asymmetries

From the simple description of the results, it is possible to synthesize the analysis model through two-way ANOVA (two factors of variability) to evaluate the existence of significant differences in salaries both at the country level and at the role level.

In addition, two-way ANOVA (see Table 3) confirms the existence of significant asymmetries between academic wages and among countries ( $\mathrm{p}$-value $=0.000 \mathrm{~F}=7.10$ ) between the four academic positions ( $\mathrm{p}$-value $=0.000 \mathrm{~F}=41.37$ ).

The competition, innovation and growth in 2010 notes that in countries where in-

Table 3. ANOVA test results.

\begin{tabular}{cccccc}
\hline Origin of the variation & $S Q$ & $g d l$ & $M Q$ & $F$ & $p$-value \\
\hline Between states & $43,873,560,517$ & 25 & $1,754,942,421$ & 10.0787 & 0.000000 \\
Between the roles & $21,611,152,904$ & 3 & $7,203,717,635$ & 41.3714 & 0.000000 \\
Error & $13,059,210,931$ & 75 & $174,122,812.4$ & & \\
Total & $\mathbf{7 8 , 5 4 3 , 9 2 4 , 3 5 1}$ & $\mathbf{1 0 3}$ & & & \\
\hline
\end{tabular}

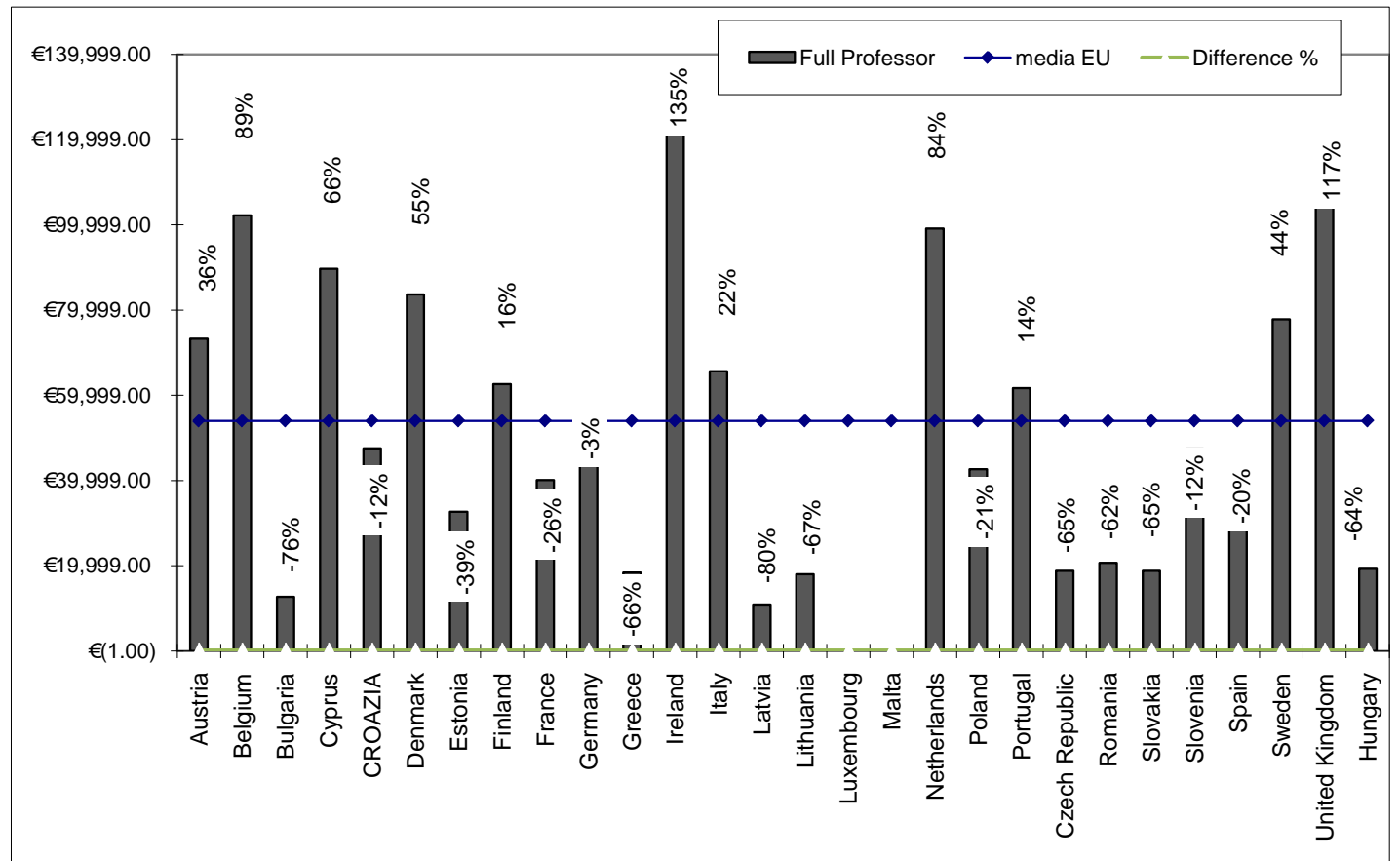

Figure 4. Representation of the average salaries for full Professor role. Source: our elab. About information taken from corporate websites of the Ministries of individual countries-year 2013. 


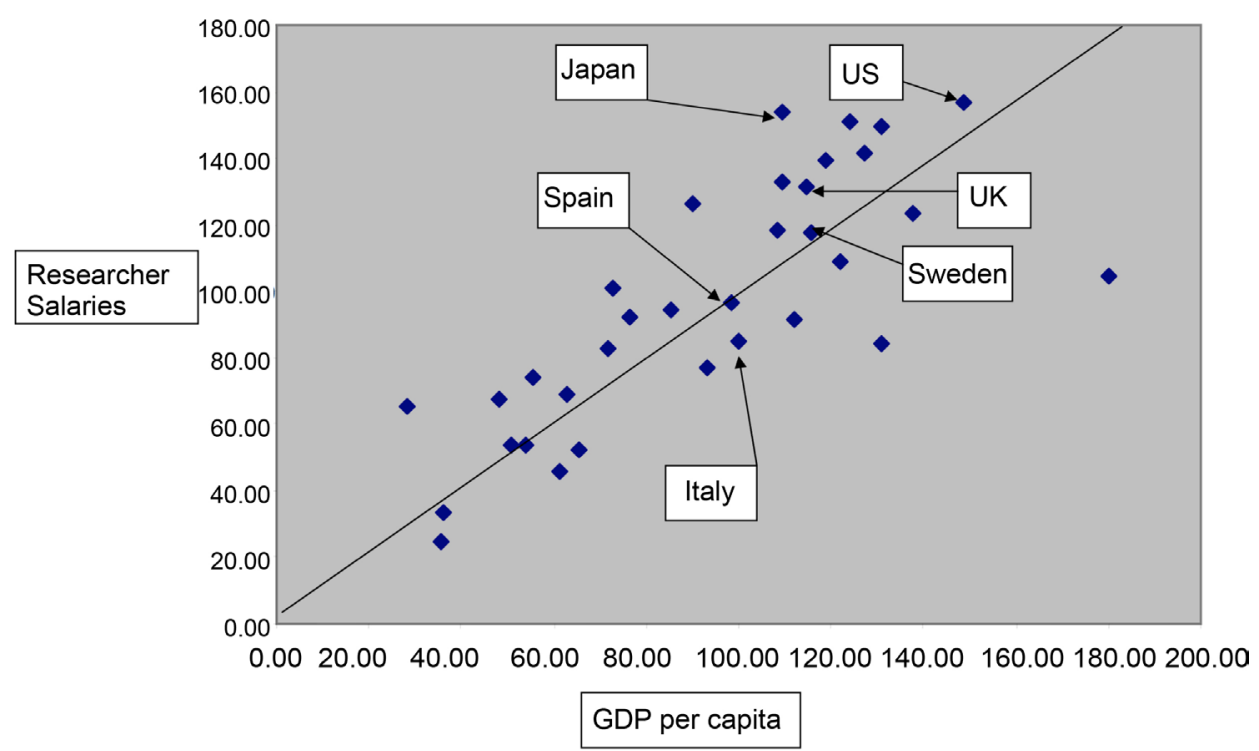

Figure 5. Scatterplot between researcher salaries level and GDP per capita. Source: taken from Competition, Innovation and Growt, 2010.

vestments in R \& D are also the largest, the GDP is higher (see Figure 5).

If we displayed the wages in individual academic positions per country to the indicators of wealth, we observe interesting results.

The simple generalization of the relationship between wages and GDP does not meet our testing for the presence of diversity.

It 'clear that in this relationship of almost linear relationship between GDP and academic salaries there will be countries where more investment in R\&D involving higher wages, but this also correlates with the development of wealth.

If we compare the wages in individual academic positions per country to the indicators of wealth, we observe interesting results.

From this vision, we have developed relations between the wage levels and GDP per capita in a single academic role.

The charts provide a representation of how the individual European countries are organized, based on the relation between the academic position and the salary GDP per capita (see Figure 6).

In particular, from reading the charts, countries such as Denmark, Sweden, the UK, and Austria are at the top of the relation between wages and GDP per capita for all of the academic roles. However, in countries with a low GDP, low wages are recorded.

This linear relationship between wages and GDP is strong and is observed for all academic roles (see Figures 6(a)-(d)). The positions of some States are different but the trends remain the same between the roles. Leading countries in this report are the same if you also record the higher wages. These analyses confirm the theories seen in the theoretical framework: the convergence of higher wages and higher productivity.

In addition, the estimate of regressive parameters between the GDP per capita and the wages for academic roles shows that the wages will grow, on average, by one point 


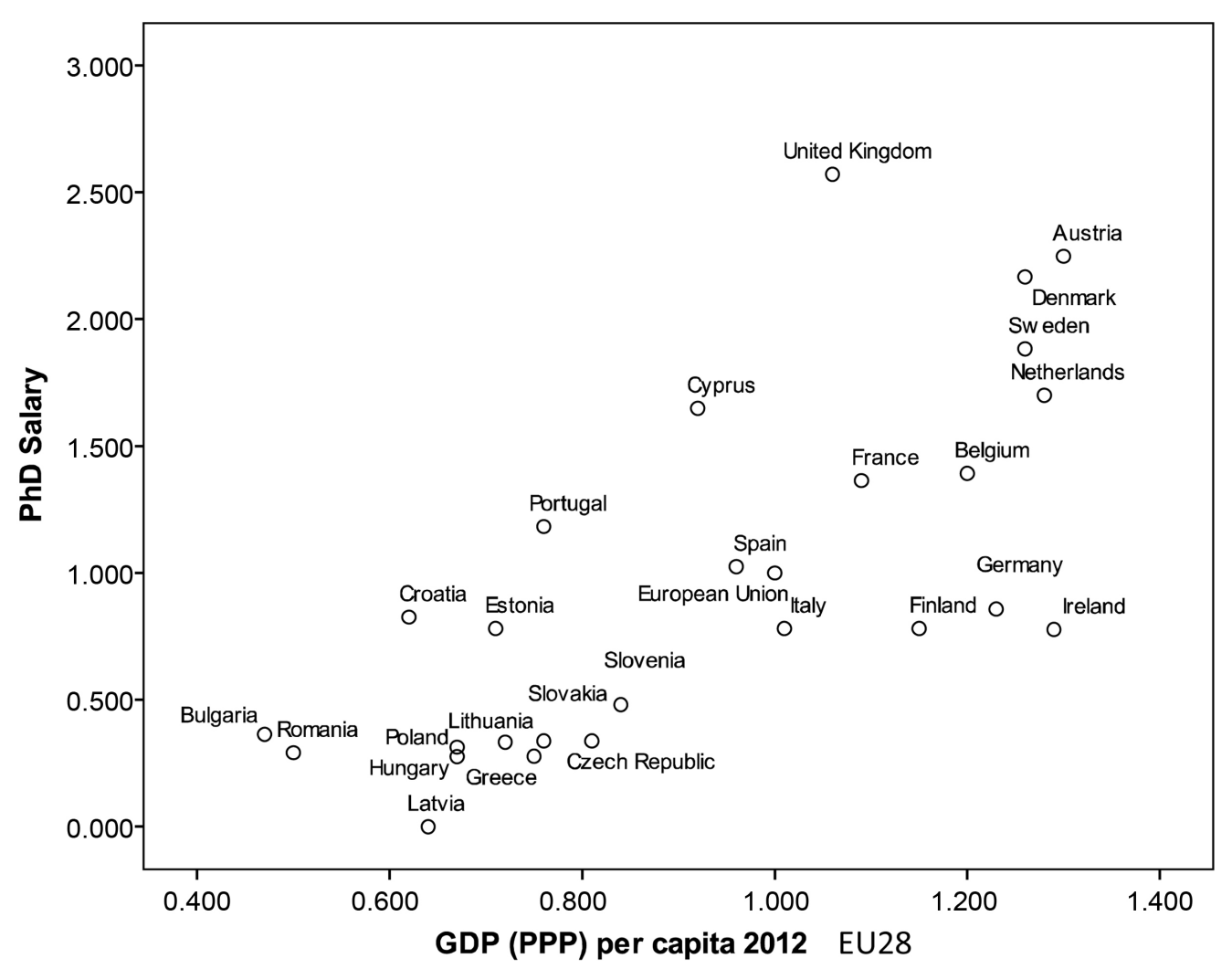

(a)

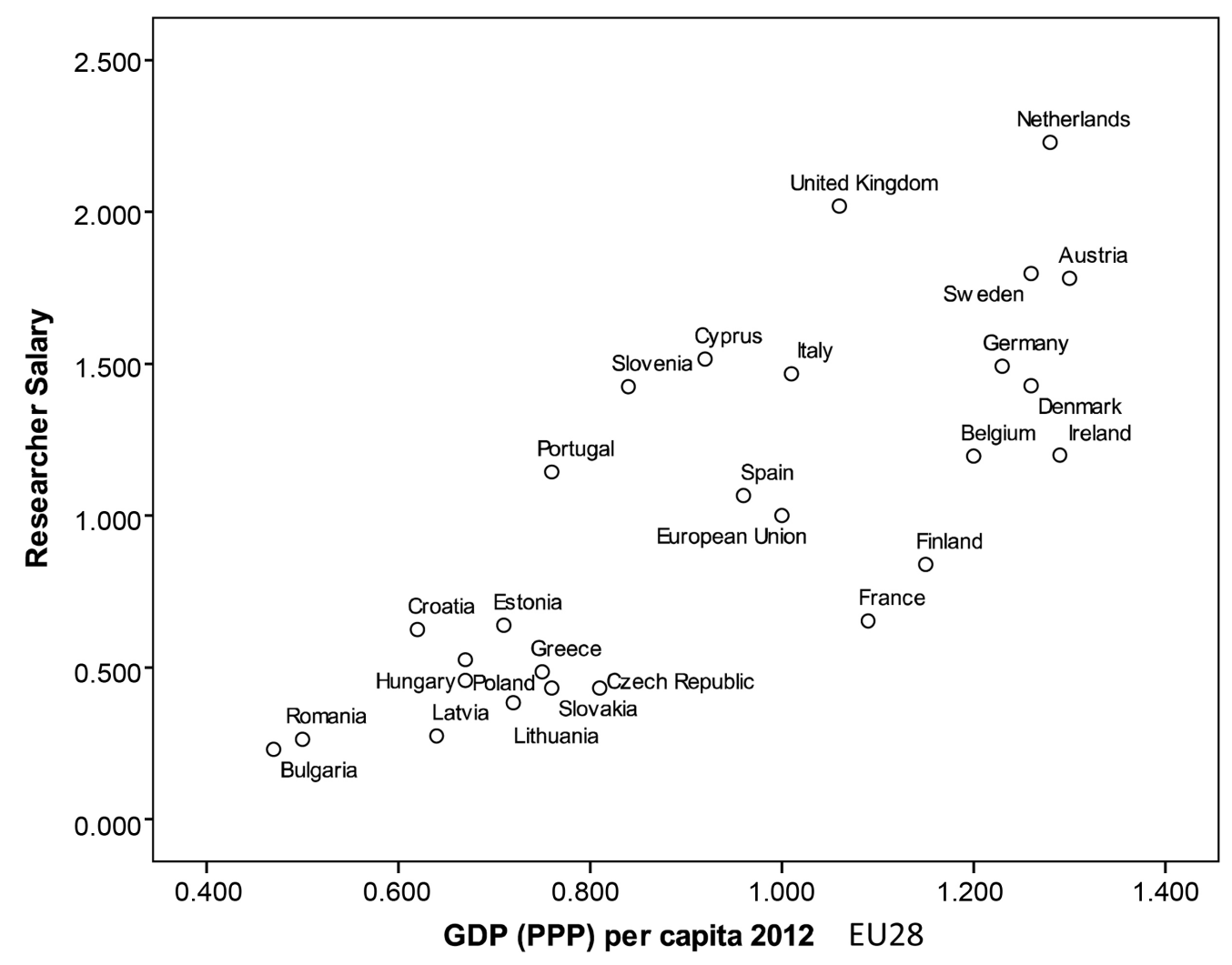

(b) 


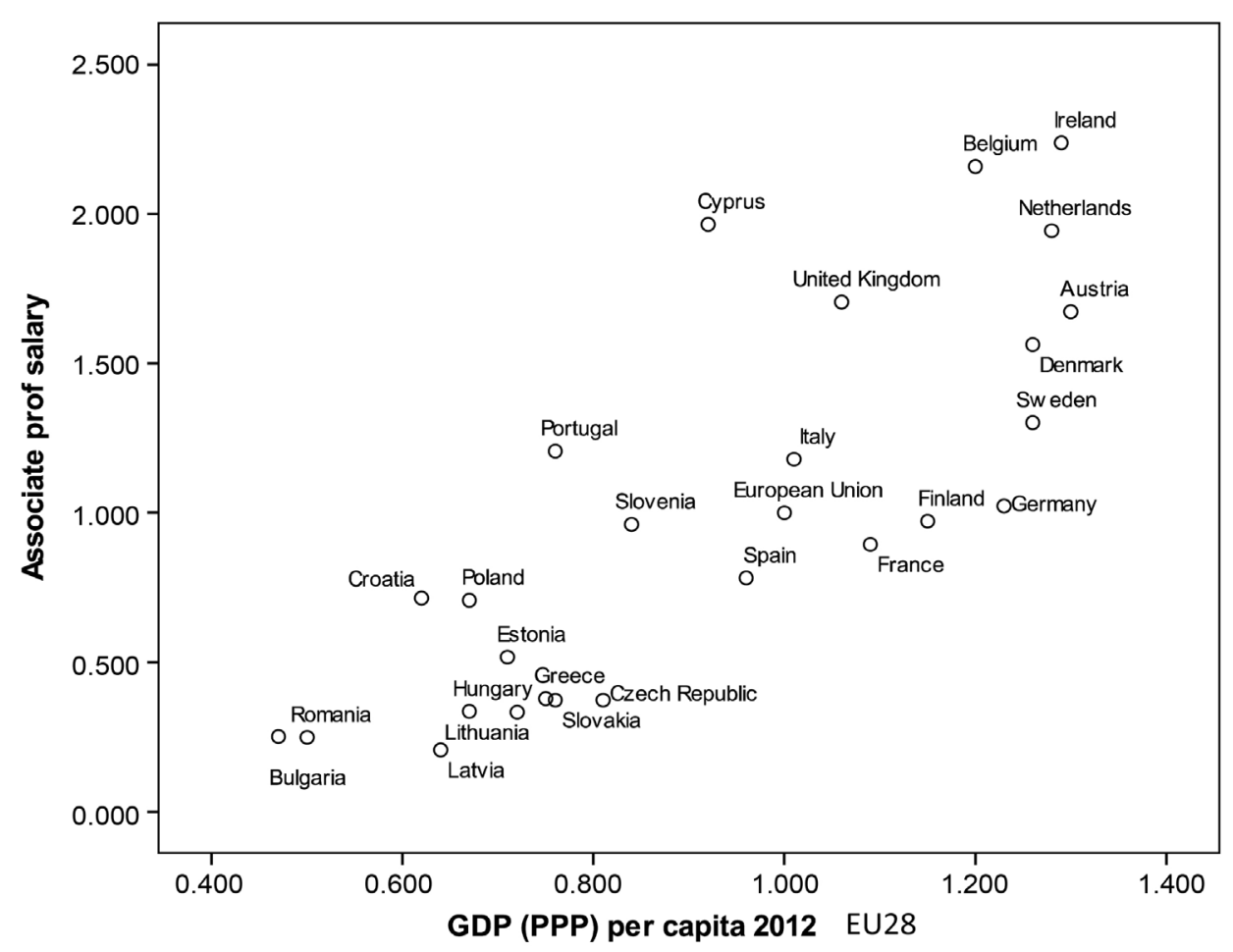

(c)

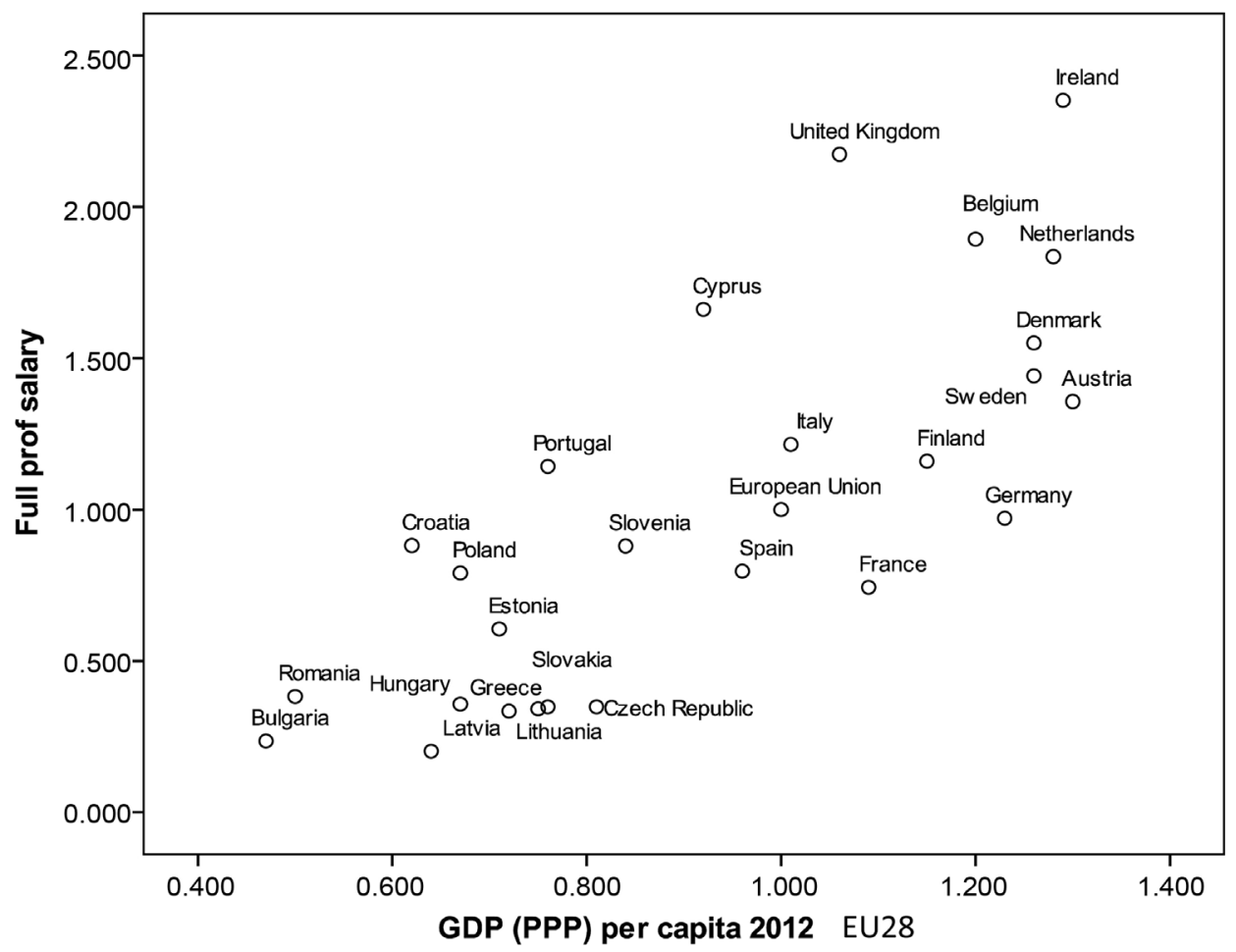

(d)

Figure 6. (a) Scatterplot between PhD salaries and GDP per capita in EU28. (b) Scatterplot between researcher (assistant professor) salaries and GDP per capita in EU28. (c) Scatterplot between associate professor salaries and GDP per capita in EU28. (d) Scatterplot between full professor salaries and GDP per capita in EU28. 
per capita GDP; wages rise by an average of $€ 1800$ in each country. In particular, this report shows that there is more growth in the role of Associate Professor, by EUR 1923, on average. The wage growth for a $\mathrm{PhD}$ is $€ 1892$; for the role of researcher, it is EUR 1754, and for a full Professor, it is 1817 euro (see Table 4).

The techniques adopted to provide an analysis of the asymmetries at the salary levels are sufficiently representative. The vision of an asymmetric phenomenon can take on the character of duality or patchiness.

Through a clustering model that weighs the links between the factors (coded with $1=$ $\mathrm{PhD} ; 2=$ researcher; $3=$ associate professor; and $4=$ full professor) of similarity, it is possible to reconstruct a more precise asymmetry. The results obtained lead to five different clusters.

In the first cluster (see Figure 7) included Austria, Sweden, Denmark, the UK, Cyprus and the Netherlands. Within this cluster, we obtained four different relations. Between Austria and Sweden, there is consistency between wages in various academic positions: $\mathrm{PhD}$, Researcher and Full Professor, as well as Sweden and Denmark. However, between Denmark and Austria, the homogeneity is present for the $\mathrm{PhD}$, Researcher and Associate Professor positions. In the second report, which includes the UK and Austria, there is consistency between the wages regarding the Phd, Researcher and Associate

Table 4. RL results.

\begin{tabular}{|c|c|c|c|c|}
\hline & $\mathrm{PhD}$ & Assistant professor & Associate professor & Full professor \\
\hline $\mathrm{R}$ square & 0.48 & 0.62 & 0.636 & 0.594 \\
\hline $\mathrm{F}$ & 25,751 & 40,757 & 43,617 & 36,624 \\
\hline $\mathrm{p}$-value & $0.000^{\mathrm{a}}$ & $0.000^{\mathrm{a}}$ & $0.000^{\mathrm{a}}$ & $0.000^{\mathrm{a}}$ \\
\hline$\beta$ & 1892 & 1754 & 1923 & 1817 \\
\hline $\mathrm{T}$ & 5075 & 6384 & 6604 & 6052 \\
\hline $\mathrm{p}$-value & $0.000^{\mathrm{a}}$ & $0.000^{\mathrm{a}}$ & $0.000^{\mathrm{a}}$ & $0.000^{\mathrm{a}}$ \\
\hline
\end{tabular}

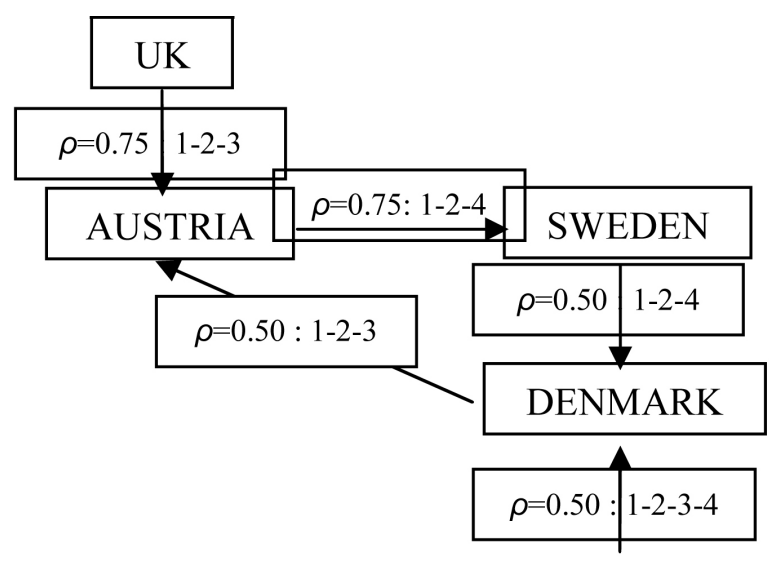

CYPRUS

Figure 7. Cluster n. 1 (Cl1) results. 
Professor positions; finally, in the third and fourth reports, there is uniformity in wages in all four positions between Cyprus and Denmark.

In the second cluster (see Figure 8), there is homogeneity between Belgium and Ireland in the Associate Professor and Researcher positions.

In the third cluster (see Figure 9), I included three countries: Bulgaria, Romania and Latvia. There is uniformity of salaries in the $\mathrm{PhD}$, Researcher and Associate Professor positions between Bulgaria and Romania and between Romania and Latvia. Between Romania and Bulgaria, homogeneity of wages exists between PhD, Researcher and Full Professor.

In the fourth cluster (see Figure 10), I included seven countries: Portugal, Italy, Finland, Germany, Slovenia, Spain and France. In this cluster, three relations of homogeneity are configured. Portugal is associated with Italy and Finland aggregates with Italy; Italy is associated with Germany, Slovenia and Spain, whereas France is associated with Spain.

Finally (see Figure 11), the fifth cluster is composed of five countries: Greece, Czech Republic, Slovakia, Hungary and Lithuania. Within this cluster, three reports are configured, and all have consistency between wages in all of the academic positions: the first relationship is between Greece and the Czech Republic, Slovakia and Czech Republic, Slovakia and Greece; the second relationship is between Hungary and the Czech Republic; and the third and final link is between Lithuania and the Czech Republic.

This type of graphical representation provides a clear picture of the disproportions

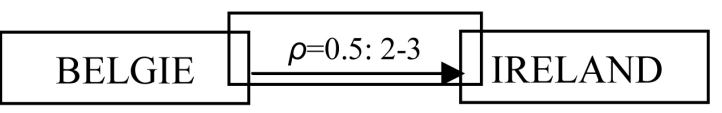

Figure 8. Cluster n. $2(\mathrm{Cl} 2)$ results.

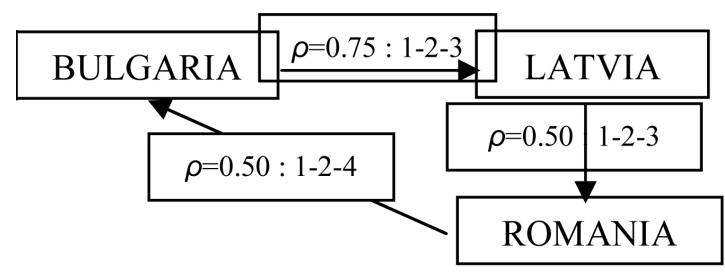

Figure 9. Cluster n. $3(\mathrm{Cl} 3)$ results.

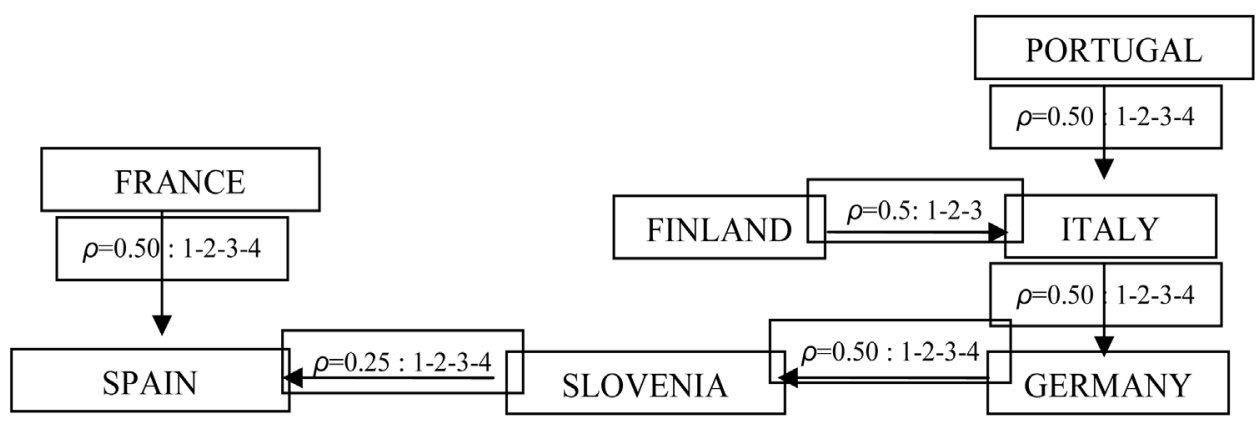

Figure 10. Cluster n. $4(\mathrm{Cl} 4)$ results. 


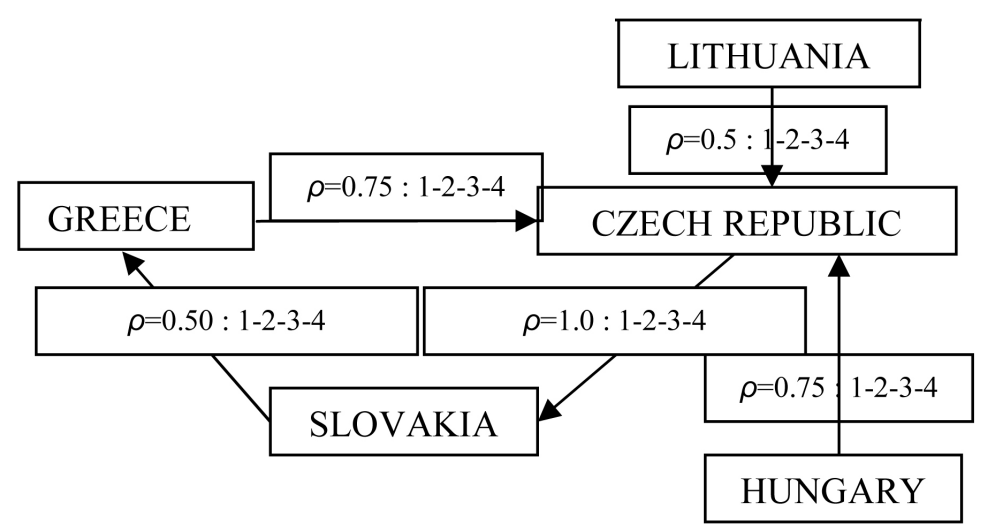

Figure 11. Cluster n. $5(\mathrm{Cl} 5)$ results.

that exists intra-Europe between countries and of the aggregation factors that configure homogeneity. From this, analysis emerges assessments regarding academic-related salary differentials between different types of contracts, with the indicators of wealth per capita, with the indices of well-being and with both academic positions.

In addition to measuring academic salary, we asked ourselves what factors can cause these differences in academic payrolls. We considered variables of context, macroeconomic variables and variables related to the labour contract; the variables for each European country follow:

$X_{0}=$ average annual wage-average wage weighted more than the weight of the roles.

$X_{1}=$ Load students/teachers-this is one of many indicators of the workload of researchers and teachers.

$X_{2}=$ HID index on the economic well-being of a country.

$X_{3}=$ HSID-complex indicators on the economic well-being of a country.

$X_{4}=$ Benefit Income-this is an indicator based on the employment contract of each country analysed. It is that portion of the salary related to the presence or absence (dummy) of productivity bonuses or to the achievement of specific objectives by academic role.

$X_{5}=$ Objective criteria in the career roles-we considered the presence or absence (dummy) of objective criteria in the evaluation system on the stages of progress in the career roles. We consider this an index of the assessment of the merit-based bonus system.

$X_{6}=$ Number of publications-indicator of a further aspect of the productivity of teachers.

$X_{7}=$ Teachers with less than forty years-indicator of the average time to achieve the roles of the teacher. For us, it represents an indicator of the assessment of the speed of access to higher academic positions.

$X_{8}=$ Quote R\&D-an indicator of the amount of financial resources allocated to each country for scientific research.

The correlation matrix (see Table 5) represented by the following statistically significant relations: 
Table 5. Matrix correlation results.

\begin{tabular}{|c|c|c|c|c|c|c|c|c|c|c|}
\hline & & $X_{0}$ & $X_{1}$ & $X_{2}$ & $X_{3}$ & $X_{4}$ & $X_{5}$ & $X_{6}$ & $X_{7}$ & $X_{8}$ \\
\hline \multirow{2}{*}{$X_{0}$} & $\rho=$ & 1 & -0.012 & 0.292 & $0.389^{*}$ & $0.518^{*}$ & $0.723^{\star *}$ & 0.219 & 0.033 & $0.463^{*}$ \\
\hline & $\mathrm{p}$-value & & 0.953 & 0.139 & 0.041 & 0.005 & 0 & 0.263 & 0.867 & 0.013 \\
\hline \multirow{2}{*}{$X_{1}$} & $\rho=$ & -0.012 & 1 & $-0.443^{*}$ & $-0.389^{*}$ & -0.017 & -0.163 & -0.127 & -0.257 & -0.068 \\
\hline & $\mathrm{p}$-value & 0.953 & & 0.021 & 0.041 & 0.931 & 0.407 & 0.519 & 0.187 & 0.731 \\
\hline \multirow{2}{*}{$X_{2}$} & $\rho=$ & 0.292 & $-0.443^{\star}$ & 1 & $0.724^{\star \star}$ & 0.079 & 0.138 & -0.051 & 0.318 & 0.369 \\
\hline & $\mathrm{p}$-value & 0.139 & 0.021 & & 0 & 0.695 & 0.492 & 0.801 & 0.106 & 0.058 \\
\hline \multirow{2}{*}{$X_{3}$} & $\rho=$ & $0.389^{*}$ & $-0.389^{*}$ & $0.724^{\star *}$ & 1 & 0.274 & $0.442^{*}$ & 0.129 & -0.036 & $0.456^{*}$ \\
\hline & $\mathrm{p}$-value & 0.041 & 0.041 & 0 & & 0.158 & 0.018 & 0.513 & 0.855 & 0.015 \\
\hline \multirow{2}{*}{$X_{4}$} & $\rho=$ & $0.518^{\star *}$ & -0.017 & 0.079 & 0.274 & 1 & $0.495^{\star *}$ & 0.353 & -0.043 & $0.697^{* *}$ \\
\hline & $\mathrm{p}$-value & 0.005 & 0.931 & 0.695 & 0.158 & & 0.007 & 0.065 & 0.828 & 0 \\
\hline \multirow{2}{*}{$X_{5}$} & $\rho=$ & $0.723^{\star *}$ & -0.163 & 0.138 & $0.442^{*}$ & $0.495^{* *}$ & 1 & 0.261 & -0.11 & $0.513^{* *}$ \\
\hline & $\mathrm{p}$-value & 0 & 0.407 & 0.492 & 0.018 & 0.007 & & 0.18 & 0.579 & 0.005 \\
\hline \multirow{2}{*}{$X_{6}$} & $\rho=$ & 0.219 & -0.127 & -0.051 & 0.129 & 0.353 & 0.261 & 1 & 0.004 & 0.132 \\
\hline & $\mathrm{p}$-value & 0.263 & 0.519 & 0.801 & 0.513 & 0.065 & 0.18 & & 0.985 & 0.504 \\
\hline \multirow{2}{*}{$X_{7}$} & $\rho=$ & 0.033 & -0.257 & 0.318 & -0.036 & -0.043 & -0.11 & 0.004 & 1 & -0.233 \\
\hline & $\mathrm{p}$-value & 0.867 & 0.187 & 0.106 & 0.855 & 0.828 & 0.579 & 0.985 & & 0.233 \\
\hline \multirow{2}{*}{$X_{8}$} & $\rho=$ & $0.463^{*}$ & -0.068 & 0.369 & $0.456^{*}$ & $0.697^{\star *}$ & $0.513^{\star *}$ & 0.132 & -0.233 & 1 \\
\hline & p-value & 0.013 & 0.731 & 0.058 & 0.015 & 0 & 0.005 & 0.504 & 0.233 & \\
\hline
\end{tabular}

- The average annual salary in the EU countries increases with the economic wellbeing of the country, and it is positively correlated to the index, HSID ( $\rho=0.389$; p-value $=0.041$ )

-Countries in which they are granted benefits for productivity register higher wages; the correlation is positive ( $\rho=0.518$; p-value $=0.005)$.

-The correlation is positive between the merit award system and the level of wages $(\rho=0.723$; p-value $=0.000)$.

-The relation between the amount of financial resources for research and development is positive for the wage level $(\rho=0.463$; -value $=0.013)$.

By refining the analysis model, we obtain estimate of the extent of the impact of the factors analysed and the average wage in European countries.

Also these results confirm the initial theory. Higher wages generate higher productivity. Higher wages generate economic prosperity and high employment and a better organizational climate. These relationships are biunivocal and not univocal. It means that there is a relationship of reciprocity.

We used a regression model that is generalized for dummies.

The results (see Table 6) show that the model explains $62.5 \%$ of the total variability $(\mathrm{F}=23,464 ; \mathrm{p}$-value $=0.000)$. 
Table 6. (a) Model summary. (b) Coeffincient regression results.

(a)

\begin{tabular}{|c|c|c|c|c|c|c|}
\hline Model & $\mathrm{R}$ & R Square & $\begin{array}{l}\text { Adjusted R } \\
\text { Square }\end{array}$ & $\begin{array}{l}\text { Std. Error of } \\
\text { the Estimate }\end{array}$ & & \\
\hline 1 & $0.808^{\mathrm{a}}$ & 0.652 & 0.625 & 6762.84 & & \\
\hline \multicolumn{7}{|c|}{ ANOVA $^{\mathrm{b}}$} \\
\hline \multicolumn{2}{|r|}{ Model } & Sum of Squares & $\mathrm{df}$ & Mean Square & $\mathrm{F}$ & Sig. \\
\hline \multirow{3}{*}{1} & Regression & $7.644 \mathrm{E}+09$ & 2 & $3.822 \mathrm{E}+09$ & 23.464 & $0.000^{\mathrm{a}}$ \\
\hline & Residual & $4.072 \mathrm{E}+09$ & 25 & $1.629 \mathrm{E}+08$ & & \\
\hline & Total & $1.172 \mathrm{E}+10$ & 27 & & & \\
\hline
\end{tabular}

aPredictors: (Constant), GDP, Ostacoli. ${ }^{b}$ Dependent Variable: average annual wage.

(b)

\begin{tabular}{ccc}
\hline & & $\mathrm{X}_{0}$ \\
\hline & Constant & 9221.30 \\
& $\mathrm{p}$-value & 0.043 \\
$X_{3}$ & $\beta=$ & 577.35 \\
& $\mathrm{p}$-value & 0.0005 \\
$X_{4}$ & $\beta=$ & 12370.91 \\
& $\mathrm{p}$-value & 0.000 \\
$X_{5}$ & $\beta=$ & 18979.026 \\
& $\mathrm{p}$-value & 0.006 \\
$X_{8}$ & $\beta=$ & 970.37 \\
& $\mathrm{p}$-value & 0.033 \\
\hline
\end{tabular}

The results of the regressive coefficients provide the following information: one additional point of economic well-being (HSID) inside on average salary of 57,735 Euros; States with labour contracts that provide benefits or productivity bonuses have an impact on the average salary of EUR 1,237,091; the presence of meritocratic criteria on the State of academic positions produces average wages above 18 thousand euro. Finally, a percentage point higher in the share of research and development has an average salary impact of 97,037 Euro.

$$
X_{0}=922,130+577.35 X_{3}+1,237,091 X_{4}+18,979,026 X_{5}+97,037 X_{8}+676,284
$$

The regressive parameters represent the measure of the average change that exists among the analyzed factors and the salary level of a State. This analysis model has possible to identify and estimate the factors statistically significant on wages.

The complex of calculations performed provides a representation of various aspects of wage asymmetry in Europe:

-It describes the wage differences between countries for different roles;

-It measures the relationship between the wage and the wealth of a State; 
-Verify the composition of the clusters and in relation to which roles are realized the similarity groups;

-It calculates the relationships between some of the economic factors, the environment and contract with the salary;

-Estimate the extent of the impact of the most significant factors statistically wages of European States.

\section{Conclusions}

European academic labor markets are experiencing many changes aiming at similar objectives: the establishment of better regulated internal labor markets and the affirmed role of the university level in the management of the newly introduced incentive mechanisms. This general trend carries with it comparable implications. The presence in Europe of an academic systems salary, which is clustered into five groups, certainly limits the European vision of the academic system; in addition, the influence of factors characterizing each country or each group confirms the assumption.

These differences can be attributed to local context factors, contractual factors and factors such as economic well-being.

These three main systems interact strongly with the level of wages in Europe; they exert a positive influence on the average wage.

With this study we can not support the initial hypothesis of this paper. In Europe it is not possible to hypothesize a single model of salaries for academics.

The policy that should be adopted imagines a unified European wage model. This policy should standardize plans for funding research, identifying relationships with businesses and the territory, monitoring the academic productivity, and developing a single contract system and an equal in value related to the GDP of each country.

Complex and large policies do not suggest possibilities for the development of a unique academic model wage.

Our attempt to study the diversity and wage determinants leads us to these conclusions, which have enabled us to provide a broad understanding of the phenomena studied and the reasons for refusal.

\section{References}

[1] Altbach, P.G., Reisberg, L. and Pacheco, I.F. (2013) Academic Salaries and Contracts: Global Trends and American Realities. The NEA Almanac of Higher Education.

[2] Scott, C.S. and Siegfried, J.J. (2011) Comparison of Salaries of University Professors around the World.

[3] Musselin, G. (2005) European Academic Labor Markets in Transition. Higher Education, 49, 135-154. https://doi.org/10.1007/s10734-004-2918-2

[4] Greenbaum, R.T. (2002) A Spatial Study of Teachers' Salaries in Pennsylvania School Districts in. Journal of Labor Research, 23, 69-86. https://doi.org/10.1007/s12122-002-1019-1

[5] Altbach, P.G., Reisberg, L., Yudkevich, M., Androushchak, G. and Pacheco, I.F. (2012) Paying the Professoriate: A Global Comparison of Compensation and Contracts. Routledge, 
London.

[6] Bruegel (2007) Why Reform Europe's University? Policy Brief Series.

[7] Cebula, R.J., Mixon Jr., F.G. and Montez, M.A. (2013) Teachers' Salaries and Human Capital, and Their Effects on Academic Performance: An Institution-Level Analysis of Los Angeles County High Schools. Journal of Economics and Finance, 39, 347-356. https://doi.org/10.1007/s12197-013-9261-3

[8] Ferreyra, M.M. and Liang, P.J. (2012) Information Asymmetry and Equilibrium Monitoring in Education. Journal of Public Economics, 96, 237-254.

https://doi.org/10.1016/j.jpubeco.2011.07.012

[9] MORE2 (2013) Support for Continued Data Collection and Analysis Concerning Mobility Patterns and Career Paths of Researchers. Brussels.

[10] MORE2 (2012) Support for Continued Data Collection and Analysis Concerning Mobility Patterns and Career Paths of Researchers. Brussels.

[11] European Commission (2011) Eurydice: La rete di informazione sull'istruzione in Europa. Eurydice.

[12] European Commission (2008) Higer Education Governance in Europe: Policies, Structures, Funding and Academic Staff. Eurydice.

[13] European Commission (2011) Remuneration of Researchers in Public and Private Sector.

[14] Skonieczny, G. and Torrisi, B. (2002) Cluvar: A Grouping Technique of Statistic Unit and Variables Selection.

Submit or recommend next manuscript to OALib Journal and we will provide best service for you:

- Publication frequency: Monthly

- 9 subject areas of science, technology and medicine

- Fair and rigorous peer-review system

- Fast publication process

- Article promotion in various social networking sites (LinkedIn, Facebook, Twitter, etc.)

- Maximum dissemination of your research work

Submit Your Paper Online: Click Here to Submit

Or Contact service@oalib.com 